\title{
Uprising period and elevation of the Wenyu granitic pluton in the Xiaoqinling District, Central China
}

\author{
YU XinQi ${ }^{1}{ }^{*}$, LIU JunLai ${ }^{1}$, ZHANG DeHui $^{1}$, ZHENG Yong $^{2}$, LI ChunLin ${ }^{1}$, \\ CHEN ShuaiQi ${ }^{1} \&$ LI Tan ${ }^{3}$ \\ ${ }^{1}$ School of the Earth Sciences and Resources, China University of Geosciences, Beijing 100083, China; \\ ${ }^{2}$ Institute of Geology and Geophysics, Chinese Academy of Sciences, Beijing 100029, China; \\ ${ }^{3}$ Surveying and Mapping Institute of Geology and Mineral Resources of Liaoning Province, Shenyang 110121, China
}

Received December 14, 2012; accepted February 28, 2013; published online August 8, 2013

\begin{abstract}
Xiaoqinling District is an important gold-producing area in China. It ranks second to Jiaodong with regard to gold deposits. The uprising period of the Wenyu granitic pluton and the wall-rocks of the deposit, as well as the mineralizing depth and reserved place of gold ore bodies, are significant to ore exploration. Fission-track (FT) analysis of zircons and apatites of granitic rocks from the Wenyu granitic pluton shows that apatite FT (AFT) data modeling indicates a rapid cooling rate of $20^{\circ} \mathrm{C} / \mathrm{Ma}$ from 138 to $120 \mathrm{Ma}$ after emplacement at $138 \mathrm{Ma}$. Thermal evolution and inversion curves suggest a secondary phase of fast cooling and uprising from 45 to $35 \mathrm{Ma}$, and $35 \mathrm{Ma}$, respectively, with a cooling rate of $6.7^{\circ} \mathrm{C} / \mathrm{Ma}$ and a denudation quantity of $\sim 4.3 \mathrm{~km}$. The last cooling phase took place from $<4 \mathrm{Ma}$, with an average cooling rate of $\sim 11.3^{\circ} \mathrm{C} / \mathrm{Ma}$ and a denudation amount of $1.3 \mathrm{~km}$. Total exhumation quantity of $5.6 \mathrm{~km}$ and uprising elevation of $7.3 \mathrm{~km}$ are similar to the estimated results of fluid inclusions from the Dongtongyu and Wenyu gold deposits. The ${ }^{39} \mathrm{Ar} /{ }^{40} \mathrm{Ar}$ dating of sericite from the fault planes of the Xunmadao-Xiaohe and Taiyao faults demonstrate two uprising activities of the ore-host metamorphic complex. The Huashan and Wenyu granitic plutons intensively occurred during 77 and $45 \mathrm{Ma}$, respectively. These data sets are valuable for understanding the uplifting process and for preserving gold ore bodies in the Xiaoqinling area, as well as for further studies on tectonic evolutions of the Taihua Complex and the Qinling-Dabie Orogen.
\end{abstract}

apatite fission track, ${ }^{39} \mathrm{Ar} /{ }^{40} \mathrm{Ar}$ dating, uplift and exhumation, Wenyu granitic pluton, metamorphic complex

Citation: Yu X Q, Liu J L, Zhang D H, et al. Uprising period and elevation of the Wenyu granitic pluton in the Xiaoqinling District, Central China. Chin Sci Bull, 2013, 58: 4459-4471, doi: 10.1007/s11434-013-5830-2

Xiaoqinling District, a part of the northern margin of the Qinling-Dabie Orogen, is located in the south margin of the North China Craton (NCC) or the southernmost segment of the Trans-North China Orogen (TNCO) in the west-east direction. Xiaoqinling District is structurally bound by the northern Taiyao Fault and southern Xunmadao-Xiaohe Fault. The Taihua Complex, which is the main metamorphic basement previously known as the Xiaoqinling Precambrian terrain, consists of granitic and pegmatitic gneiss, biotiteplagioclase gneiss, hornblende-plagioclase gneiss, magnetite quartzites, amphibolite, leucoleptites, granulites, marble,

*Corresponding author (email: yuxinqi@cugb.edu.cn) and localized eclogite enclaves. Several granitic veins are emplaced into granitic gneiss. Recent sensitive highresolution ion microprobe (SHRIMP) and laser ablationinductively coupled-mass spectrometry (LA-ICP-MS) U-Pb zircon ages of the Taihua Complex indicate that the complex was formed during the Paleoproterozoic [1-4].

Xiaoqinling District is an important gold-producing area in China. It ranks second to Jiaodong with regard to gold deposits. Detecting the location of ore bodies, as well as determining the period and altitude of gold ore bodies and wall-rock uplifts, are crucial for prospecting. Debates on whether a metamorphic core complex exists and when the complex rapidly uplifted have attracted considerable atten- 
tions among geologists. $\mathrm{Hu}$ et al. $[5,6]$ proposed that the Xiaoqinling metamorphic core complex is symmetrical in structural pattern. The core of the metamorphic core complex consists of ancient gneiss from Taihua Complex and Yanshanian granites. The Xiaoqinling metamorphic core complex developed two detachment fault systems on both the north and south borders, namely, Taiyao-Guxian Fault and Xunmadao-Xiaohe Fault, respectively. These borders constitute a horst-shaped structural system. As the hanging wall of the fault, the cap rock with a rigid basement produces an extensional detachment along the detachment fault. Zhang et al. [7], as well as Zhang and Zheng [8], considered the Xiaoqinling metamorphic core complex as the back part of the Yanshanian orogenic wedge of the north Qinling nappe structure. The core complex and the east-southeastwest-northwest (ESE-WNW) detachment fault system were formed through the thickened-nappe structure and the emplacement of deep magma during the synorogenic extension at $135 \mathrm{Ma}$. This extension was followed by intensive magmatic emplacement after $123 \mathrm{Ma}$, which led to further uprising of the metamorphic core complex. Zhang et al. [9] argued that the north rim faults of the Xiaoqinling area were trust nappe faults before $123 \mathrm{Ma}$; however, all north and south rim piedmont faults shifted to normal faults after 123 Ma and destroyed the ore bodies. Zhang et al. [10-14] suggested that the Yanshanian tectonic environment transformed into the an intracontinental orogeny domain, where the regional N-S compressional stress field led to the overthrust of the Early-Middle Cretaceous folded strata upon the Triassic strata in the Shangdan Basin. In the Late Cretaceous, large-scale nappe structures occurred on both sides of the Qinling orogen and caused this orogenic belt to uprise rapidly because of the subduction of the Yangtze and North China Blocks beneath the Qinling orogen. Through the systematic analysis of the internal folds and peripheral faults in the Taihua Complex in the Xiaoqinling area, combined with the analysis of regional dynamic evolution, Li et al. [15] negated the occurrence of metamorphic core complex and suggested that the uprising of the Taihua Complex is related to the S-N nappe structures and the development of later high-dip angle normal faults.

Located at the northern part of the Qinling-Dabie orogen, the tectonic occurrence and evolution of the Xiaoqinling area was severely influenced and restricted by those of the Qinling-Dabie Orogen. Considerable progress in the research on the Qinling orogenic belt has been achieved in the recent years [13,14,16-24]. The Qinling-Dabie orogen, lasting about $600 \mathrm{Ma}$, is a typical "composite orogen" that underwent two collision events during the Devonian and Triassic Periods and an intracontinental orogeny during the Cretaceous $[20,21,24,25]$. The orogenic activity in the Qinling area during the Late Jurassic to the Early Cretaceous was caused by neither the collision related to plate subduction nor the remote effect of plate tectonics, but by the intracontinental orogen not related to the tectonic dynamic
[14]. The Qinling composite orogen eventually formed by the intracontinental orogen overlapped previous collisions related to plate subduction [14]. The rapid uplifting of the Qinling orogen began in the Late Cretaceous and continued during the Cenozoic [26]. Liu et al. [27] studied the uprising period of the Taibai Mountain in the Qinling orogen during the Cenozoic and proposed that the Qinling area underwent a rapid uplifting-cooling process at approximately $48 \mathrm{Ma}$ and a more rapid uplifting-cooling process at approximately 9.6 Ma. Two uplifting processes correspond to the two stretching deformations of the north part of the Qinling Mountains. The uprising in $48 \mathrm{Ma}$ is related to the remote effect caused by the collision between the Indian Plate and the Eurasian Plate. By contrast, the uprising in $9.6 \mathrm{Ma}$ is most likely associated with the rapid uprising and expansion of the Tibetan Plateau.

However, except for studies on fluid inclusion from gold deposits, few constraints were found on the uprising period, rate, and denudation process of Xiaoqinling area, especially at the Wenyu granitic pluton near the Wenyu and Dongtongyu gold deposits. This situation restricts further ore prospecting. Fission-Track (FT) analysis, which allows dating of cooling events affecting the first few kilometers of the crust [28-37], is used to better constrain the age of the onset of uplift and denudation process in the Wenyu granitic pluton. Studies on the upliftng process of the Wenyu granitic pluton may not only provide better insight into the tectonic background of the area, but also valuable information on the uplift and preservation of the Xiaoqinling gold deposits as well as the tectonic evolution of the metamorphic complex.

\section{The Wenyu granitic pluton}

Two-stage granitic plutons exist in the Xiaoqinling area. Early-stage granites include Paleoproterozoic Guijiayu and Xiaohe plutons, distributed in the south part of Xiaoqinling District and occupying a small area. Guijiayu pluton mainly comprises amphibolite monzogranite and biotite hornblende granite. Xiaohe pluton mainly comprises biotite monzogranite. By contrast, late-stage Yanshanian granitic plutons exist in Xiaoqinling District as a huge batholith intruding in the Precambrian Taihua Complex and covering a large area. The Laoniushan, Huashan, Wenyu, and Niangniangshan granitic plutons are located from west to east (Figure 1), with their outcrop areas gradually diminishing. Petrological assemblages of late-stage granites are mainly biotite monzonitic granite and biotite granite. Wenyu and Niangniangshan plutons are approximately 71 and $31 \mathrm{~km}^{2}$ in outcrop area, respectively. In addition, basic dykes are widespread in the Xiaoqinling area. These dykes were formed during the Caledonian, Yanshanian, and Himalayan Periods, and were mainly composed of diabase, gabbro-diabase, gabbro-allgovite, gabbro-porphyrite, and lamprophyre. 


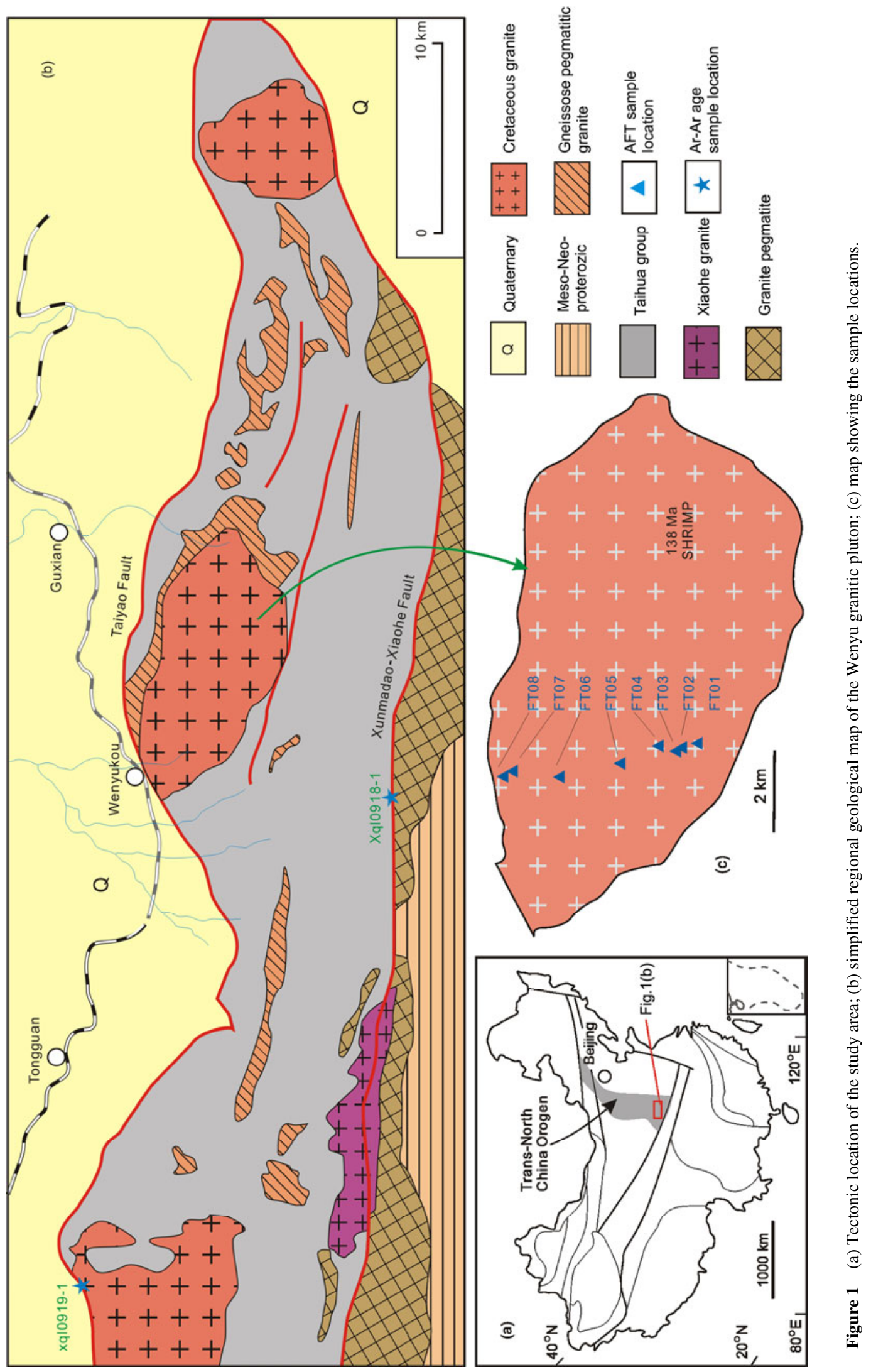


The Wenyu granitic pluton is located in the mid-east region of the Xiaoqinling area. According to regional geological data, the Wenyu granitic pluton can be divided into three facies, namely, marginal, transitional, and central. Marginal facies are a fine- or medium-fine-grained porphyritic biotite monzogranites, with $100-200 \mathrm{~m}$ assimilation and contamination outer contact zones. Transitional facies are mainly ash grey porphyritic medium-grained biotite monzogranites, occupying the biggest area of $32 \mathrm{~km}^{2}$. Central facies are ash grey porphyritic fine-grained biotite monzogranites.

Wang et al. [38] presented SHRIMP zircon U-Pb dating and geochemistry for Wenyu and Niangniangshan plutons in the Xiaoqinling area. Results indicate that both Wenyu and Niangniangshan plutons are I-type granites, derived from the partial melting of Archaean high-grade metamorphic rocks from the Taihua Complex. The ages of these plutons are $138.4 \pm 2.5 \mathrm{Ma}$ and $141.7 \pm 2.5 \mathrm{Ma}$, respectively. Such ages are earlier than the period of detachment event, thus indicating that the Xiaoqinling metamorphic core complex was formed by a hot magmatic dome and the intrusion of granitic magma. This magma originated from the partial melting of the middle-lower crust and then intruded into the upper crust [38]. Zhao et al. [39] reported the LA-ICP-MS zircon $\mathrm{U}-\mathrm{Pb}$ ages of $131 \pm 1 \mathrm{Ma}$ and $134 \pm 1 \mathrm{Ma}$ for the Wenyu and the Niangniangshan plutons, respectively. Gao et al. [40] respectively gained the ages of $135 \pm 7 \mathrm{Ma}$ and $139 \pm 4 \mathrm{Ma}$ for biotite monzongranite from the Wenyu and Niangniangshan plutons via LA-ICP-MS zircon U-Pb dating. They indicated that plutons were formed in the Early Cretaceous, and petrologic features were similar to those of adakitic affinity formed by partial melting of the thickened lower crust. Xiao et al. [41] proposed that during the Early Cretaceous, the tectonic regime transitioned from a compressional system to an extensional system; and large-scale lithosphere delamination/thinning caused magmatism and gold metallogenesis in the Xiaoqinling area and its vicinity. Under combined decompression and underplating, ancient crust materials underwent partial melting and led to the formation of adakite-like granite in the study area.

\section{Samples and analytical methods}

The FT technique is based on counting damage tracks before and after irradiation generated by splitting heavy nuclides into two-charged fragments moving repidly in a crystal lattice. The introduction of age standards externaldetector (ED), and annealing models [42] led to the development of AFT geochronology, which was initially a dating method, into a powerful tool for uncovering thermal evolution both in the orogen and in the basin [43-45]. AFT parameters, such as single-grain age, and confined-track length with occasional apatite chemical analyses, and other low-medium temperature chronological methods are essen- tial for thermal-evolution modeling of rocks from a shallow crust. This type of modeling will be more reliable and quantitative if experimental annealing models are improved practically [26,46-48].

Unweathered rocks of Wenyu granite were sampled linearly from the top (near the Tianyi Palace) to the foot of the Yawu Mountain, Lingbao County, Henan Province for AFT analyses. Altitude separation of each sample was about 200 $\mathrm{m}$, and the weight of the samples ranged from 1.5 to $2.0 \mathrm{~kg}$. A pocket global positioning system, combined with elevation correction on 1/50000 maps, was used to locate samples (Figure 1).

After crushing, separating, and airing, apatite and zircon grains were separated and selected under binoculars using the standard magnetic and heavy-liquid techniques. Individual apatite and zircon grains were respectively mounted in epoxy resin and fluorinated ethylene propylene Teflon, polished to expose internal grain surfaces, and packed together with muscovite EDs. The samples were analyzed using an ED method [49] at the Institute of High Energy Physics, Chinese Academy of Sciences. Spontaneous FT lengths in apatite grains were revealed via etching using $6.6 \% \mathrm{HNO}_{3}$ at $25^{\circ} \mathrm{C}$ for $30 \mathrm{~s}$. Sample grains were packed together with Corning CN5 glass dosimeters irradiated in the 492 Swim-Pool hot-neutron nuclear reactor at the China Institute of Atomic Energy, Beijing. The reactor is thermalized well with a $\mathrm{Cd}$ ratio for $\mathrm{Au}>100$. After irradiation, muscovite EDs were detached and etched in $40 \% \mathrm{HF}$ at $25^{\circ} \mathrm{C}$ for $35 \mathrm{~min}$ to reveal induced FTs. Ages were calculated using the Zeta calibration method $[42,50]$ and the standard FT age equation [51]. In this study, we obtained the Zeta constant of AFT, i.e. 332.1 $\pm 10.5(1 \sigma)$. Samples were exposed to ${ }^{252} \mathrm{Cf}$ [45] to increase the number of observable horizontal-confined tracks. Horizontal-confined FT lengths $[52,53]$ were measured only in prismatic apatite crystals because of the anisotropy of annealing of FTs in apatite [46].

\section{Analytical results and explanations}

AFT analytical results are listed in Table 1 . At least 28 grains of apatite from each sample were analyzed because of the high content of the Wenyu granitic pluton.

AFT ages of the samples mainly range from 32 to $42 \mathrm{Ma}$. All samples have a concordance of ages within the standard deviation range (SDR), except FT07, thus implying that FT results were affected by a unit-fast tectonothermal event [54]. Mean track lengths (MTL) vary from $12.7 \pm 1.8 \mu \mathrm{m}$ to $13.0 \pm 2.0 \mu \mathrm{m}$, which are almost the same as those within the SDR. Long MTLs with large SDR indicate a long period within the apatite partial annealing zone (PAZ). Length distribution shows a broad skew (Figure 5), which is usually interpreted in terms of a protracted thermal event.

Zircon FT (ZFT) ages of the Wenyu samples range from 
Table 1 The apatite fission-track test data for the Wenyu granitic pluton ${ }^{\text {a) }}$

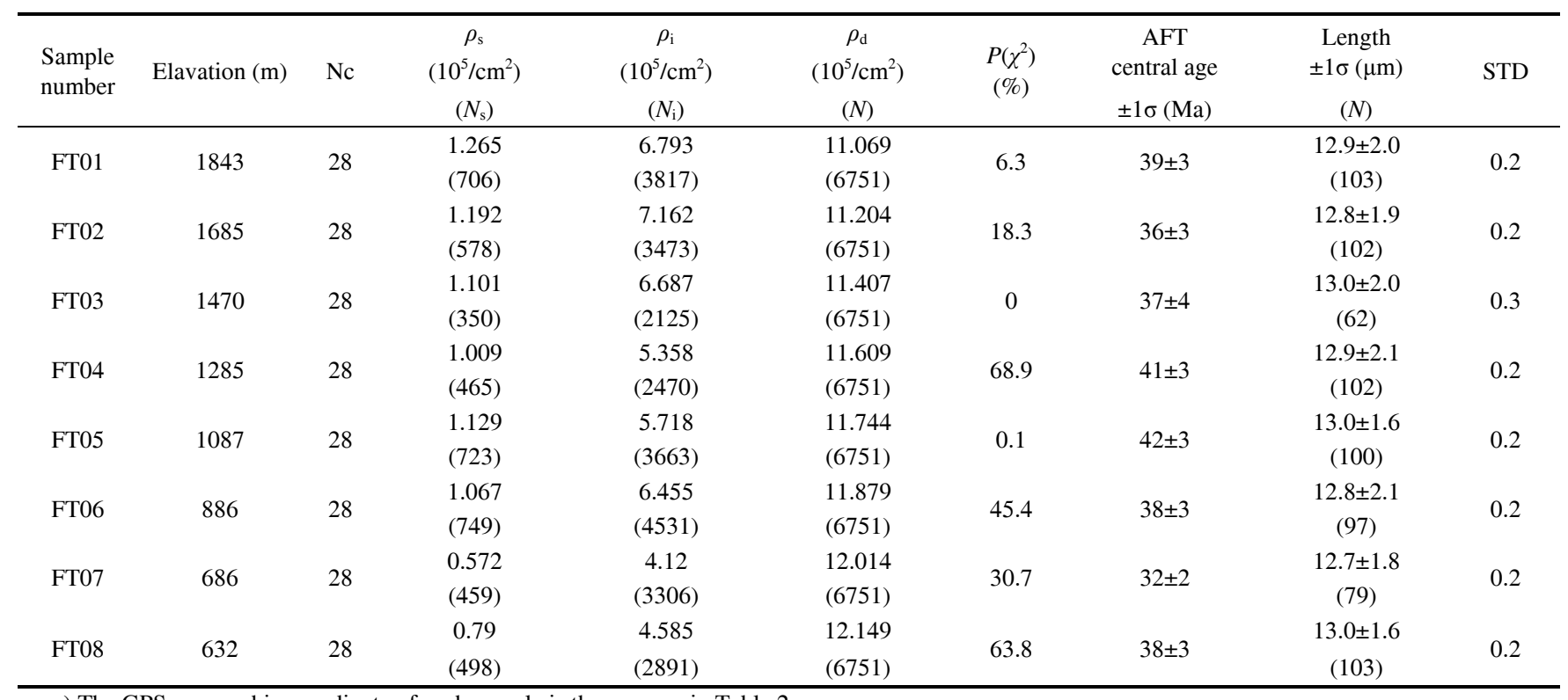

a) The GPS geographic coordinate of each sample is the same as in Table 2 .

Table 2 The zircon fission-track test data for the Wenyu granitic pluton

\begin{tabular}{|c|c|c|c|c|c|c|c|c|}
\hline $\begin{array}{l}\text { Sample } \\
\text { number }\end{array}$ & $\begin{array}{l}\text { GPS } \\
\text { geographic } \\
\text { coordinate }\end{array}$ & Elavation (m) & $\mathrm{Nc}$ & $\begin{array}{c}\rho_{\mathrm{s}} \\
\left(10^{5} / \mathrm{cm}^{2}\right) \\
\left(N_{\mathrm{s}}\right)\end{array}$ & $\begin{array}{c}\rho_{\mathrm{i}} \\
\left(10^{5} / \mathrm{cm}^{2}\right) \\
\left(N_{\mathrm{i}}\right)\end{array}$ & $\begin{array}{c}\rho_{\mathrm{d}} \\
\left(10^{5} / \mathrm{cm}^{2}\right) \\
(N)\end{array}$ & $\begin{array}{l}P\left(\chi^{2}\right) \\
(\%)\end{array}$ & $\begin{array}{c}\text { ZFT } \\
\text { central age } \\
\pm 1 \sigma(\mathrm{Ma})\end{array}$ \\
\hline FT02 & $\begin{array}{l}34^{\circ} 27^{\prime} 50.8^{\prime \prime} \mathrm{N}, \\
110^{\circ} 26^{\prime} 09.7^{\prime \prime} \mathrm{E}\end{array}$ & 1685 & 21 & $\begin{array}{l}59.979 \\
(2040)\end{array}$ & $\begin{array}{l}37.605 \\
(1279)\end{array}$ & $\begin{array}{l}8.972 \\
(5656)\end{array}$ & 0 & $62 \pm 6$ \\
\hline FT04 & $\begin{array}{l}34^{\circ} 28^{\prime} 11.4^{\prime \prime} \mathrm{N}, \\
110^{\circ} 26^{\prime} 10.2^{\prime \prime} \mathrm{E}\end{array}$ & 1285 & 12 & $\begin{array}{l}67.380 \\
(1073)\end{array}$ & $\begin{array}{c}55.763 \\
(888)\end{array}$ & $\begin{array}{l}8.757 \\
(5656)\end{array}$ & 73.2 & $45 \pm 3$ \\
\hline FT05 & $\begin{array}{l}34^{\circ} 28^{\prime} 37.7^{\prime \prime} \mathrm{N}, \\
110^{\circ} 25^{\prime} 58.0^{\prime \prime} \mathrm{E}\end{array}$ & 1087 & 6 & $\begin{array}{c}71.315 \\
(680)\end{array}$ & $\begin{array}{c}59.045 \\
(563)\end{array}$ & $\begin{array}{l}8.511 \\
(5656)\end{array}$ & 52.9 & $45 \pm 3$ \\
\hline FT06 & $\begin{array}{l}34^{\circ} 29^{\prime} 29.9^{\prime \prime} \mathrm{N}, \\
110^{\circ} 25^{\prime} 47.4^{\prime \prime} \mathrm{E}\end{array}$ & 886 & 10 & $\begin{array}{l}78.242 \\
(1046)\end{array}$ & $\begin{array}{c}58.794 \\
(786)\end{array}$ & $\begin{array}{l}8.388 \\
(5656)\end{array}$ & 9.6 & $47 \pm 4$ \\
\hline FT07 & $\begin{array}{l}34^{\circ} 30^{\prime} 11.4^{\prime \prime} \mathrm{N} \\
110^{\circ} 25^{\prime} 51.2^{\prime \prime} \mathrm{E}\end{array}$ & 686 & 12 & $\begin{array}{c}106.851 \\
(1523)\end{array}$ & $\begin{array}{l}77.455 \\
(1104)\end{array}$ & $\begin{array}{l}8.204 \\
(5656)\end{array}$ & 2.8 & $48 \pm 4$ \\
\hline FT08 & $\begin{array}{l}34^{\circ} 30^{\prime} 16.2^{\prime \prime} \mathrm{N}, \\
110^{\circ} 25^{\prime} 43.9^{\prime \prime} \mathrm{E}\end{array}$ & 632 & 14 & $\begin{array}{c}108.291 \\
(1799)\end{array}$ & $\begin{array}{l}92.038 \\
(1529)\end{array}$ & $\begin{array}{l}8.081 \\
(5656)\end{array}$ & 1.1 & $43 \pm 3$ \\
\hline
\end{tabular}

43 to $61 \mathrm{Ma}$ (Table 2). Although mineral compositions in the granite area are similar, $<0.05 \chi^{2}$ values of most zircon samples reflect a wide range of single-grain ages that do not fall within the same suit of ages, thus resulting in statistical error. Given that the distribution of counts were inconsistent with purely Poissonian variation [55,56], the pooled age was adopted, which was simply the sum of the spontaneous counts divided by the sum of the induced counts [57]. ZFT ages are all younger than the formation age of the plutons from which the samples were collected, thus indicating that the samples experienced post-thermal events [58] within the zircon PAZ. The point of inflexion on the zircon age-absolute elevation curve at $\sim 1250 \mathrm{~m}$ (Figure 2) marks the base of an exhumed PAZ (Figure 3). Samples above the point of inflexion are experienced significant annealing with consistent $t$ time in the PAZ prior to rapid cooling; whereas samples below the point of inflexion accumulated nothing from the FT because they remained in the full annealing zone until the following rapid uprising were carried them to the PAZ. Therefore, rapid denudation occurred since $45 \mathrm{Ma}$, which corresponded to the turnoff age (at the point of inflexion). The slope of the zircon age curve indicates that the 
denudation rate was $\sim 23.03 \mathrm{~m} / \mathrm{Ma}$ above the point of inflexion, which was equivalent to a cooling rate of $0.8^{\circ} \mathrm{C} / \mathrm{Ma}$, whereas the denudation rate reached $277 \mathrm{~m} / \mathrm{Ma}$ with a cooling rate of $9.7^{\circ} \mathrm{C} / \mathrm{Ma}$ after the tectonic event in $45 \mathrm{Ma}$ (Figure 3).

\section{Cooling history of the Wenyu granitic pluton}

Previous thermochronology in the study area included zircon U-Pb and biotite Ar-Ar analyses. Combining AFT ages and ZFT turnoff age from the aforementioned data, a postcrystallization cooling history of the Wenyu granitic pluton was simulated using mineral-pair ages and their closure temperatures (Figure 4). The closure temperatures of zircon $\mathrm{U}-\mathrm{Pb}$ and biotite $\mathrm{Ar}-\mathrm{Ar}$ are $700 \pm 50^{\circ} \mathrm{C}$ [59] and $300 \pm 50^{\circ} \mathrm{C}$ [60], respectively. The temperature of $110 \pm 10^{\circ} \mathrm{C}$ is often referred to as the closure temperature of AFT [46]. An effective zircon closure temperature is poorly determined but is assumed as $240 \pm 30^{\circ} \mathrm{C}$ [61].

Based on the simulated post-crystallization cooling history, the Wenyu granitic pluton experienced a rapid cooling phase from 138 to $120 \mathrm{Ma}$ after the emplacement in $138 \mathrm{Ma}$. Zhang [7] believed that a synorogenic detachment of

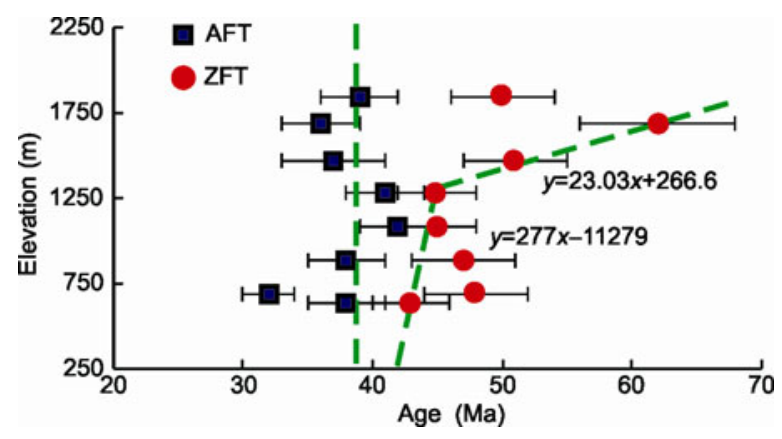

Figure 2 FT ages vs. elevations of samples.

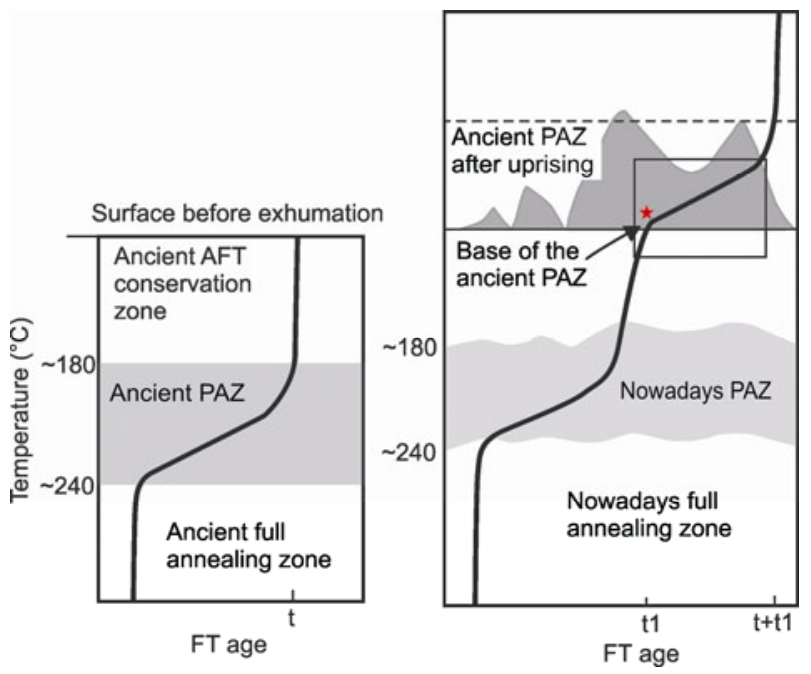

Figure 3 Cartoons illustrating the point of inflexion.

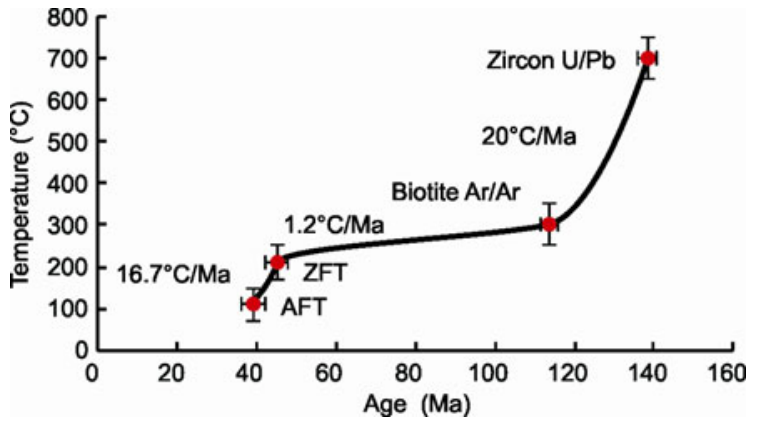

Figure 4 The mineral-pair ages thermal evolution curve of the Wenyu granitic pluton.

the Xiaoqinling area took place from 135 to $123 \mathrm{Ma}$. The decoupling event should start before $127 \mathrm{Ma}$, or at least 123 $\mathrm{Ma}$, in the course of the regional magmatic event. In 120-45 $\mathrm{Ma}$, the cooling rate decreased to $1.2^{\circ} \mathrm{C} / \mathrm{Ma}$, which was calculated based on mineral-pair ages and their closure temperatures. This result indicates that no large tectonic event has occurred. After $45 \mathrm{Ma}$ in the Eocene, the cooling rate increased to a peak value of $16.7^{\circ} \mathrm{C} / \mathrm{Ma}$ because of the fast uprising of the Wenyu granitic pluton. Liu et al. [27,62] deduced that this event is related to the collision between the India Block and the Eurasia Block at $\sim 50 \mathrm{Ma}$. This collision resulted in an initial extension and the formation of the Weihe Graben along the northern margin of the Xiaoqinling area (the southern margin of the Weihe Basin), followed by the uprising of the Qinling and Taibai Mountains [27,62]. Wang et al. [63] suggested that corresponding to the remote effect of the collision, the oldest sediments with an age of $49.2 \pm 10.2 \mathrm{Ma}$ in the Tianshui and the Huicheng Basins came from the northern margin of the Qinghai-Tibet Plateau and the episodic denudation of the western Qinling area, with the fast uplifting of Qinling Mountains. AFT results from the Micangshan-Hannan Dome area reported by Tian et al. [26] indicate that the fast denudation after $15 \mathrm{Ma}$ was a response to the northeastward propagation of the Qinghai-Tibet Plateau uplift. Zhang et al. [64] believed that the Qinghai-Tibet Plateau began to affect the adjacent area after the evolution transition period at $20 \pm(2-4)$ Ma. Both the Weihe Graben and Qinling Mountains then began to uplift rapidly, at a rate of $0.2 \mathrm{~mm} / \mathrm{a}$, after the Upper Pleistocene (5.3 Ma) and could have reached the fastest rate of $6.25 \mathrm{~mm} / \mathrm{a}$ after A.D. $721[65,66]$.

The annealing model proposed by Ketcham et al. [67] was applied in this study to reveal the cooling and exhumation history of the Wenyu granitic pluton since the Cenozoic. Monte Carlo approximation was also used to reverse analyses on thermal history by AFT. Initial conditions of the simulation were assumed to be equal to general fluorine apatite because of lack of component data. Other initial parameters of the reverse simulation were based on regional geological background and data were obtained from the test. The cooling event is assumed to start in $50 \mathrm{Ma}$, and the 
temperature began at $125^{\circ} \mathrm{C}$ (higher than the FT annealing zone) to the current surface temperature. Figure 5 shows that the thermal history of each sample obtained the best path via reverse simulation (solid line). In the figure, the dashed area represents a good fitting area, whereas the dotted line region denotes acceptability region. The upper left corner of each graph shows the sample code, the measured and simulated track lengths, the measured and simulated pooled ages, as well as the simulated and the measured values with Kolmogorov-Smirnov (K-S) test degree value and goodness-of-fit (GOF) age parameters. Simulation results are of high quality when the K-S and GOF values are greater than 0.5 . The geothermal gradient was set to $35^{\circ} \mathrm{C} / \mathrm{km}$ (close to modern data), and surface temperature was set to $10^{\circ} \mathrm{C}$.

The estimated inversion curve shows that the Wenyu granitic pluton experienced two episodes of rapid cooling since the Cenozoic. From 45 Ma to approximately 30-35 $\mathrm{Ma}$, the Wenyu granitic pluton rapidly cooled from approximately $210^{\circ} \mathrm{C}$ (at the bottom of ZFT annealing zone) to approximately $60^{\circ} \mathrm{C}$, with a cooling rate of $10^{\circ} \mathrm{C} / \mathrm{Ma}$ to $15^{\circ} \mathrm{C} / \mathrm{Ma}$, thus approximating heat evolution curves. Exhumation caused by this tectonic uplifting was approximately $4.3 \mathrm{~km}$, and the average erosion rate was approximately $0.3-0.4 \mathrm{~km} / \mathrm{Ma}$. During 30-4 Ma, the Wenyu granitic pluton underwent a calm period and the cooling rate slowed down to about $0.2^{\circ} \mathrm{C} / \mathrm{Ma}$, thus resulting in the exhumation of approximately $0.1 \mathrm{~km}$ substance. The inversion curve occurs presented an obvious inflexion in $<4 \mathrm{Ma}$, thus indicating that the cooling and uplifting events of the Wenyu granite occurred during this epoch. Consequently, temperature dropped from approximately $55^{\circ} \mathrm{C}$ to a surface temperature of $10^{\circ} \mathrm{C}$, with an average cooling rate of $\sim 11.3^{\circ} \mathrm{C} / \mathrm{Ma}$, which corresponded to a denudation rate of $\sim 0.3 \mathrm{~km} / \mathrm{Ma}$ and an eroded amount of Wenyu granite of $1.3 \mathrm{~km}$. Meanwhile, the fault depression of the Weihe Graben was obviously reinforced since $3.6 \mathrm{Ma}$ (equal to movement curtain $\mathrm{A}$ at the Tibetan Plateau, 3.6-3.4 Ma). The aforementioned graben reached the maximum sedimentary scope and fluviallacustrine area, which increased the deposition rate rapidly [64]. The rapid increase in rate was coupled by the rapid uplifting of the surroundings, including the uplift rate of the Qinling Orogen of $0.2 \mathrm{~mm} / \mathrm{a}$ since the Pleistocene (5.3 Ma) $[65,66]$. Being balanced to the rapid deposition of the Weihe Basin, the uplift rate of Xiaoqingling District should be no less than $0.2 \mathrm{~mm} / \mathrm{a}$.

Simulated thermal history of the Wenyu granitic pluton is similar to that of the Huashan granitic pluton. According to the FT thermal chronology data of Wan et al. [68] and Yin et al. [69], Wu et al. [70] analyzed the erosion history of the Huashan granitic pluton during the Cenozoic and obtained three relatively rapid uplift stages, namely, 57-42 Ma, 32-22 Ma, and approximately 8 Ma to after virtual uplift rate of approximately $0.18-0.23 \mathrm{~mm} / \mathrm{a}$. From 42 to 32 $\mathrm{Ma}$ and from 22 to $8 \mathrm{Ma}$, the Huashan granitic pluton
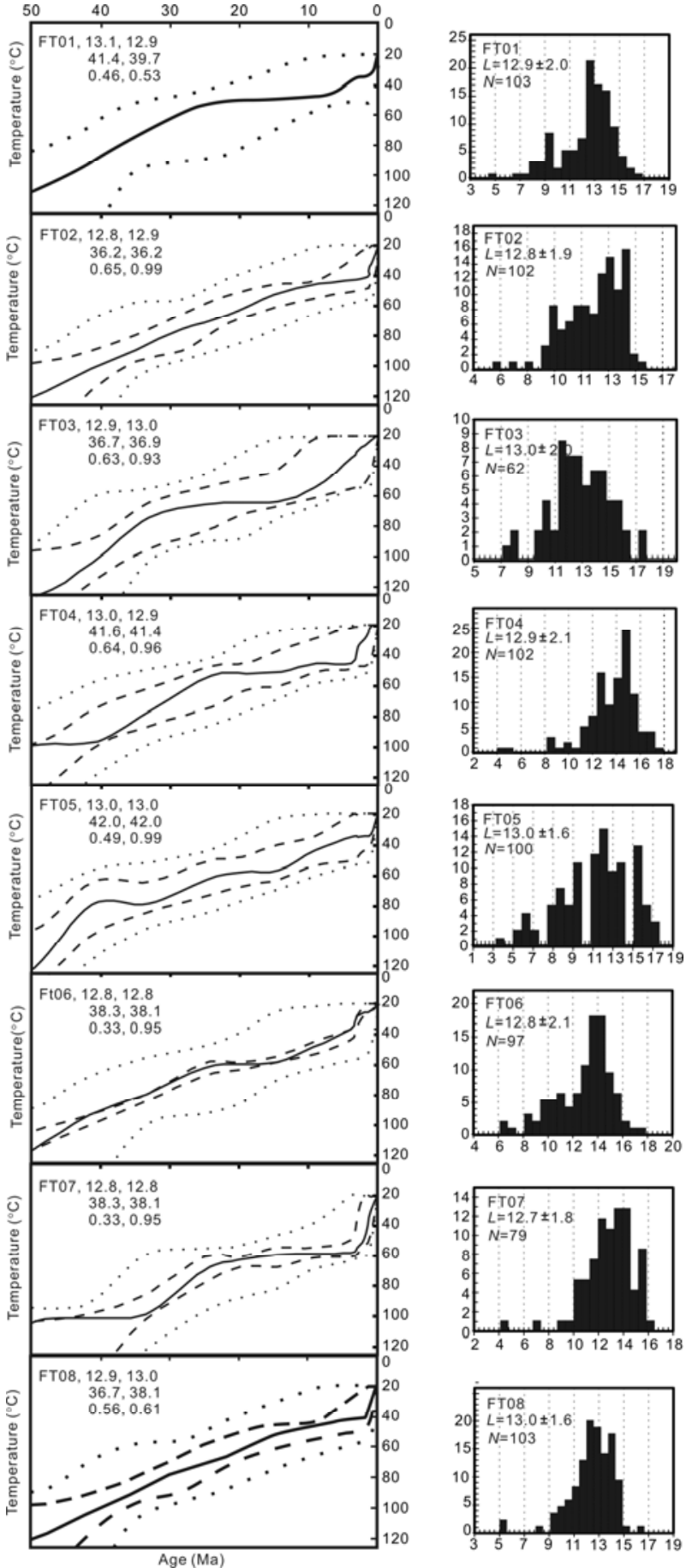

Figure 5 Simulated thermal history of the Wenyu granitic pluton.

exhibited a relatively slow uplifting process with a virtual uplift rate of only $\sim 0.01 \mathrm{~mm} / \mathrm{a}$. Since $57 \mathrm{Ma}$, the total denudation of the Huashan granite pluton is approximately 8.5 $\mathrm{km}$, and the average uplift rate is approximately $0.15 \mathrm{~mm} / \mathrm{a}$. Since $32 \mathrm{Ma}$, the total denudation is approximately 4.5-5.1 $\mathrm{km}$, and the average uplift rate is approximately $0.14-0.16$ $\mathrm{mm} / \mathrm{a}$.

Uplift elevation is close to the initial metallogenic depth of the Xiaoqinling gold deposit. The study on ore- 
forming fluid inclusions of $\mathrm{Wu}$ et al. [71] in the Dongtongyu gold deposit in the Xiaoqinling area estimated varied pressure measurements of different metallogenic stages. The estimated minimum trapping pressure measurements of the inclusions of stages I-III were respectively 123-160 $\mathrm{MPa}, 160-170 \mathrm{MPa}$, and approximately $170 \mathrm{MPa}$, which mainly concentrated at $123-170 \mathrm{MPa}$, corresponding to the minimum ore-forming depth of 4.6-6.3 km. The study on the Wenyu gold deposit of Wang et al. [72] demonstrated a middle-high ore-forming temperature of $180-450^{\circ} \mathrm{C}$ and an estimated ore-forming pressures $1.0 \times 10^{5}-1.4 \times 10^{5} \mathrm{kPa}$, corresponding to the metallogenic depth of 3.6-5.2 km. Zhou et al. [73] reported the early and middle stages of metallogenic pressure of $130-178 \mathrm{MPa}$ and $85-150 \mathrm{MPa}$ at the Wenyu gold deposit, corresponding to the metallogenic depth of 4.7-6.5 km and 3.1-5.5 km, respectively. At present, the level elevation of the mining tunnel of the Xiaoqinling gold deposit is $600-1800 \mathrm{~m}$, thus indicating that the ore body has uplifted for about 5-6 km after the metallogenic events.

\section{$5{ }^{40} \mathrm{Ar} /{ }^{39} \mathrm{Ar}$ geochronology}

The wall rock of the Wenyu granitic pluton is the Paleoproterozoic Taihua Complex, which is the primary ore-bearing rock of the Xiaoqinling gold deposit. Zhang et al. [7,8] suggested that the Xiaoqinling metamorphic core complex was formed in an extensional background during the Early Mesozoic. The youngest granite age of 135 Ma represents the lower-limit time of the detachment fault which cut the granite; and the ${ }^{40} \mathrm{Ar} /{ }^{39} \mathrm{Ar}$ cooling age of $127 \mathrm{Ma}$ denotes diorite intrusion during the late period of detachment faulting. Granitic dykes branching from the Huashan granitic pluton were $123 \mathrm{Ma}$ in ${ }^{40} \mathrm{Ar} /{ }^{39} \mathrm{Ar}$ age. These dykes intruded in the detachment fault undamaged but were cut into a domino-like shape by the succeeding collapsed stretch. Thus, the $123 \mathrm{Ma}$ age of these dykes is not only the upper-age limit for the detachment fault but also the lower-age limit for the collapse extension. The collapsed stretch might have occurred at approximately $116 \mathrm{Ma}$ because its metamorphic mylonite zone yielded the K-Ar age of 106-120 $\mathrm{Ma}$, with the isochron age of $116 \mathrm{Ma}$. Therefore, the earlier stage of the ESE-WNW trend extension of the Xiaoqinling metamorphic core complex took place from 135 to $123 \mathrm{Ma}$, and the later stage of extension caused by the post-orogenic collapse mainly occurred atapproximately $116 \mathrm{Ma}$ and became reactive at 75-71 Ma. Finally, the Xiaoqinling metamorphic core complex was uplifted and exhumed to the surface in the Palaeogene. Qiang et al. [74] conducted LA-ICP-MS U-Th- $\mathrm{Pb}$ dating for hydrothermal monazite from the Qinnan gold deposit of the Xiaoqinling ore concentration area and yielded ${ }^{206} \mathrm{~Pb} /{ }^{238} \mathrm{U}$ and ${ }^{208} \mathrm{~Pb} /{ }^{233} \mathrm{Th}$ weighted average ages of $120.9 \pm 0.9 \mathrm{Ma}(\mathrm{MSWD}=1.0)$ and $122.3 \pm 1.9 \mathrm{Ma}(\mathrm{MSWD}=2.6)$, respectively. This result indicates that the U-Th- $\mathrm{Pb}$ isotopic system of monazite has been in a closed system since the formation of the mineral-a finding which may be related to the lithospheric thinning of the NCC. Li et al. [15] pointed out that the uplifting process of the Taihua Complex in the Xiaoqinling area had been occurring since $65 \mathrm{Ma}$. Song et al. [16] believed that the northern margin of the Qinling Mountains mainly underwent uplifting and denudation since the Late Mesozoic.

Meanwhile, extracted samples of purified sericite from the two boundary faults of the Xiaoqinling metamorphic complex were used for ${ }^{40} \mathrm{Ar} /{ }^{39} \mathrm{Ar}$ dating analysis to determine the uprising period. The sampling locations are shown in Figure 1.

Samples were wrapped in Al foil tubes (0.18-0.28 mm), sealed in a quartz bottle with monitor ZBH-25 (the national Zhoukoudian K-Ar standard biotite, age = $132.7 \mathrm{Ma}$ ), and then sent to China Institute of Atomic Energy for fast neutron activation analysis. Samples and standards were irradiated for $24 \mathrm{~h}$ in a 49-2 reactor $\mathrm{B} 4$ channel, with a total flux of $2.2464 \times 10^{18} \mathrm{n} / \mathrm{cm}^{2}$. Pure $\mathrm{CaF}_{2}$ and $\mathrm{K}_{2} \mathrm{SO}_{4}$ were simultaneously irradiated, and correction factors were obtained as $\left({ }^{36} \mathrm{Ar} /{ }^{37} \mathrm{Ar}\right)_{\mathrm{Ca}}=0.000271,\left({ }^{39} \mathrm{Ar}{ }^{37} \mathrm{Ar}\right)_{\mathrm{Ca}}=0.000652$, and $\left({ }^{40} \mathrm{Ar} /\right.$ $\left.{ }^{39} \mathrm{Ar}\right)_{\mathrm{K}}=0.00703$. Samples were analyzed using a conventional ${ }^{40} \mathrm{Ar} /{ }^{39} \mathrm{Ar}$ dating system in the Key Laboratory of Orogenic Belts and Crustal Evolution, School of Earth and Space Sciences, Peking University. A Ta furnace was used to melt the minerals in a 10-14 step heating process from 800 to $1500^{\circ} \mathrm{C}$. In each step, the sample remained at a thermostatic state for $20 \mathrm{~min}$. A sponge Ta furnace, an active $\mathrm{C}$ cold trap, and a $\mathrm{Zr}-\mathrm{V}$-Fe getter were used to purify gases released by heating. Signals of the five groups of Ar isotopes were recorded using an RGA10 mass spectrograph, with the unit $\mathrm{mV}$ as signal intensity. The signals were cyclically measured nine times. For each wave, isotopic content was obtained using the peak and mean values of the two baselines preceding and succeeding the wave. The ${ }{ }^{40} \mathrm{Ar} /{ }^{39} \mathrm{Ar}$ Dating 1.2” data processing program of the Key Laboratory was employed for data reduction. Plateau and isochron ages of the samples were obtained through the Isoplot 3.0 program [75]. The details are shown in Table 3 and Figure 6.

Sample xq10918 from the tensile sliding plane of the Xunmadao-Xiaohe fault yielded an ${ }^{40} \mathrm{Ar} /{ }^{39} \mathrm{Ar}$ isochron age of 77.2 $\pm 6.8 \mathrm{Ma}(\mathrm{MSWD}=36)$ and an inverse isochron age of $77.4 \pm 6.7 \mathrm{Ma}(\mathrm{MSWD}=29)$. This result indicates that the Xunmadao-Xiaohe fault zone was activated at about $77 \mathrm{Ma}$, which is consistent with the conclusion of Zhang et al. [7,8]. Table 3 shows that the plateau age of the low-temperature phase of sample xq10919 from the tensile sliding plane of the Taiyao Fault has no effect to the fault. Meanwhile the plateau age of the high-temperature phase is $44.9 \pm 1.0 \mathrm{Ma}$ (MSWD = 0.015), with an isochron age of $41 \pm 85 \mathrm{Ma}$ (MSWD $=169$, low credibility) and a reverse isochron age of 39.6 $\pm 9.4 \mathrm{Ma}(\mathrm{MSWD}=145)$. These results indicate the occurrence of a strong tectonothermal event from 45 to 40 Ma caused by the fast sliding of the fault. 

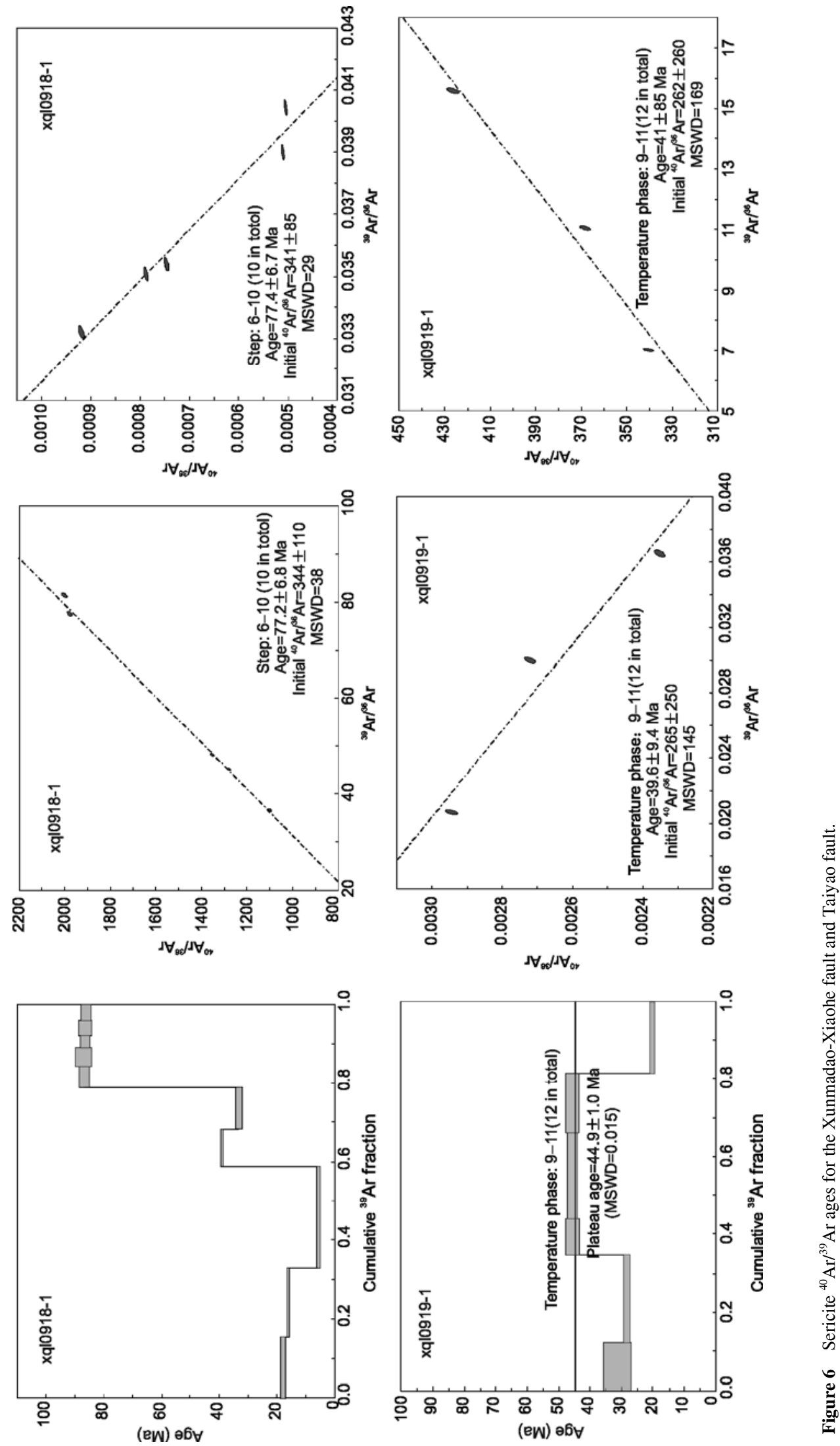


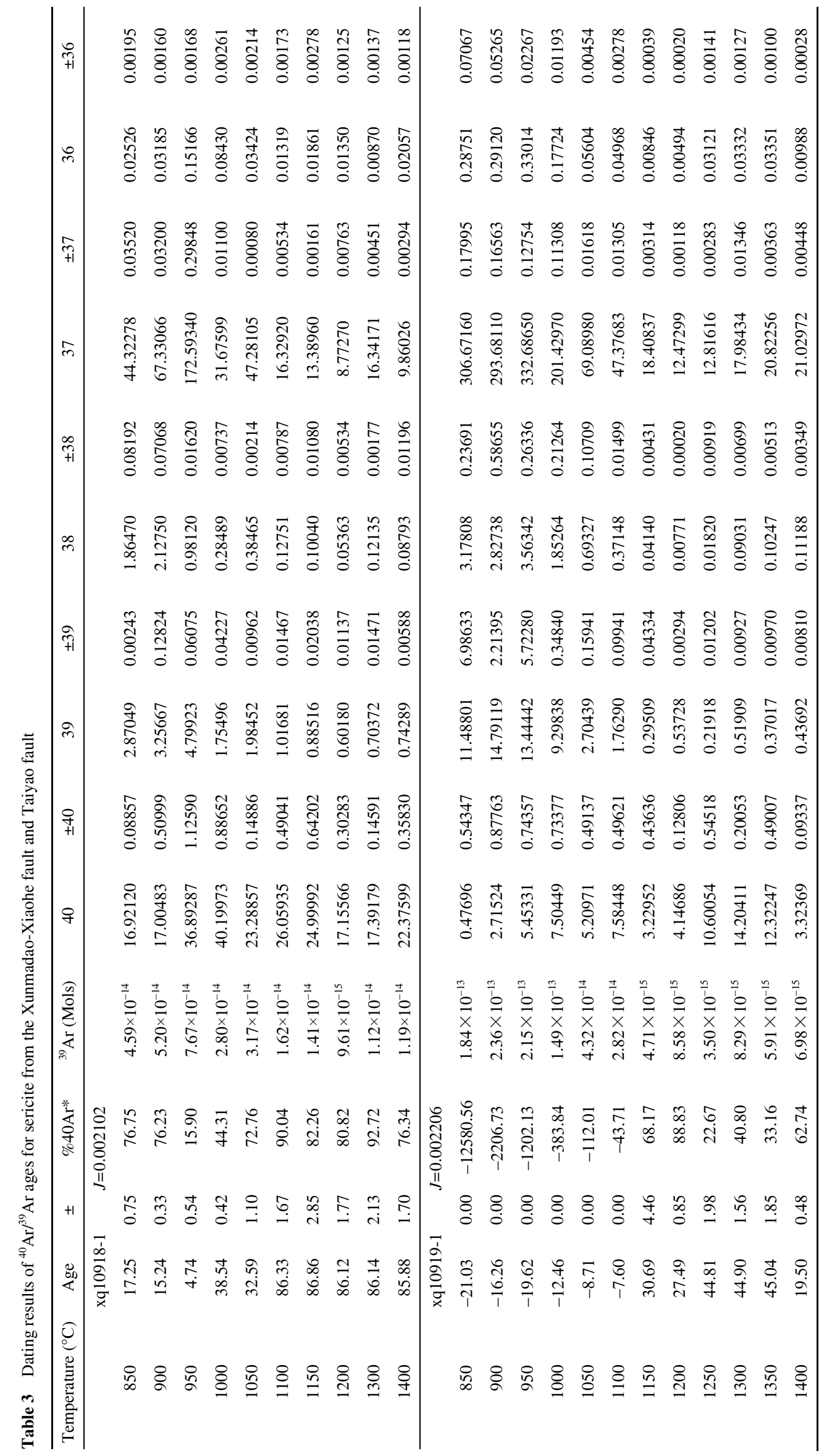


In summary, based on AFT analysis of the Wenyu granitic pluton, the rapid uprising of the Xiaoqinling metamorphic complex was influenced by the intrusion of the Huashan, Wenyu, and Niangniangshan granitic plutons, followed by another rapid uprising at approximately $45 \mathrm{Ma}$ which almost reached the current elevation.

\section{Conclusions}

The Wenyu granitic pluton in the Xiaoqinling area was investigated through low-temperature AFT and ZFT thermochronologies. Thermal evolution curves show that the Wenyu granite was formed at approximately $138 \mathrm{Ma}$ and then cooled rapidly from 138 to $120 \mathrm{Ma}$, with a cooling rate of $\sim 20^{\circ} \mathrm{C} / \mathrm{Ma}$. Thermal evolution and inversion curves show that the Wenyu granite underwent a rapid uplifting-cooling process from the Eocene Epoch ( 45 Ma) to the Oligocene Epoch (35-30 Ma), with a cooling rate of $16.7^{\circ} \mathrm{C} / \mathrm{Ma}$ and a denudation amount of $\sim 4.3 \mathrm{~km}$. Then, another uplifting-cooling process occurred after $4 \mathrm{Ma}$, with a cooling rate of $\sim 11.3^{\circ} \mathrm{C} / \mathrm{Ma}$. Corresponding to the rapid deposition in the Weihe Basin, the exhumation rate exceeded $0.2 \mathrm{~mm} / \mathrm{a}$, and the amount of denudation reached $1.3 \mathrm{~km}$. Overall, total denudation amount of the Wenyu granite was $5.6 \mathrm{~km}$, and its total uplift amplitude was $7.3 \mathrm{~km}$.

The aforementioned uplift amplitude is close to the metallogenic depth of the Xiaoqinling gold deposit. The Dongtongyu and Wenyu gold deposits are 1-1.5 km lower than the Wenyu granitic pluton in altitude, and depth estimation results from the two deposits based on the research on fluid inclusions are respectively $4.6-6.3 \mathrm{~km}$ and $3.6-5.2$ $\mathrm{km}$. Combined with sericite ${ }^{40} \mathrm{Ar} /{ }^{39} \mathrm{Ar}$ dating results of the Xunmadao-Xiaohe and Taiyao faults, all pieces of evidence indicate that the Xiaoqinling gold deposit, along with the ore-bearing metamorphic complex, Huashan and Wenyu granitic plutons, underwent rapid uplifting-cooling process at $\sim 77$ and $\sim 45 \mathrm{Ma}$; and then another uplifting-cooling process occurred after $4 \mathrm{Ma}$. All the metamorphic complex and granitic plutons were denuded at least $3-6 \mathrm{~km}$ after being uplifted at approximately $7 \mathrm{~km}$.

We thank Professor Dong Yunpeng and anonymous reviewer for their helpful comments on different versions and constructive reviews. And we appreciate Professor Xu Jiuhua, Wang Beiyi, Yang Zhihua, Ji Wenhua, Han Fanlin and Liang Binxiang for their enthusiastic help in field investigation. We are also grateful to scientists from Institute of High Energy Physics Academy of Sciences for their help in dating fission track in apatites and zircons, and scientists at the Laboratory of Orogenic Belts and Crustal Evolution (Peking University) for conducting sericite Ar-Ar dating. This work was supported by the National Natural Science Foundation of China (90814006).

1 Li H M, Chen Y C, Wang D H, et al. SHRIMP U-Pb zircon ages of metamorphic rocks and veins in the Xiaoqinling area, Henan, and their geological significance (in Chinese). Acta Petrol Sin, 2007, 23:
2504-2512

2 Diwu C R, Sun Y, Lin C L, et al. LA-(MC)-ICPMS U-Pb zircon geochronology and Lu-Hf isotope compositions of the Taihua complex on the southern margin of the North China Craton. Chin Sci Bull, 2010, 55: 2557-2571

3 Bi S J, Li J W, Li Z K. Geological significance and geochronology of Paleoproterozoic mafic dykes of Xiaoqinling gold deposit, southern margin of the North China Craton (in Chinese). Earth Sci-J Chin Univ Geosci, 2011, 36: 17-32

$4 \mathrm{Yu} \mathrm{X} \mathrm{Q,} \mathrm{Liu} \mathrm{J} \mathrm{L,} \mathrm{Li} \mathrm{C} \mathrm{L,} \mathrm{et} \mathrm{al.} \mathrm{Zircon} \mathrm{U-Pb} \mathrm{dating} \mathrm{and} \mathrm{Hf} \mathrm{isotope}$ analysis on the Taihua Complex: Constraints on the formation and evolution of the Trans-North China Orogen. Precambrian Res, 2013, 230: $31-44$

5 Hu Z G, Qian Z Z, Yan G M, et al. The Detachrnent-Metamorphic Core Complex Tectonics and the Gold Deposits in Xiaoqinling Areas (in Chinese). Xi'an: Shaanxi Science and Technology Press, 1994. 183-222

6 Hu Z G, Qian Z Z. A new idea of geological tectonics in the Xiaoqinling region (in Chinese). Geol Rev, 1994, 40: 289-295

7 Zhang J J, Zheng Y D, Liu S W. The Xiaoqinling Metamorphic Core complex: Structures, Genetic Mechanism and Evolution (in Chinese). Beijing: China Ocean Press, 1998. 1-136

8 Zhang $\mathrm{J}$ J, Zheng Y D. Multistage extension and age dating of the Xiaoqinling metamorphic core complex, central China. Acta Geol Sin, 1999, 73: 139-147

9 Zhang Y H, Li Z Y, Zhang X M, et al. Overthrust development and its relationship to gold mineralization in the northern belt of the Xiaoqinling gold (molybdenum) province, central China (in Chinese). J Jilin Univ (Earth Sci Ed), 2009, 39: 244-254

10 Zhang G W, Meng Q R, Lai S C. Tectonics and structure of the Qinling Orogenic belt. Sci China Series B, 1995, 38: 1379-1394

11 Zhang G W, Meng Q R, Yu Z P, et al. Orogenesis and dynamics of the Qinling orogen (in Chinese). Sci China Ser D-Earth Sci, 1996, 26: 193-200

12 Zhang G W, Zhang B R, Yuan X C, et al. Qinling Orogenic Belt and Continental Dynamics (in Chinese). Beijing: Science Press, 2001. 1-806

13 Zhang G W, Cheng S Y, Guo A L, et al. Mianlue paleo-suture on the southern margin of the Central Orogenic System in Qinling-DabieWith a discussion of the assembly of the main part of the continent of China (in Chinese). Geol Bull Chin, 2004, 23: 846-853

14 Zhang G W, Guo A L, Dong Y P, et al. Continental geology, tectonics and dynamics (in Chinese). Earth Sci Front, 2011, 18: 1-12

$15 \mathrm{Li} \mathrm{N} \mathrm{Z,} \mathrm{Yu} \mathrm{Z} \mathrm{P,} \mathrm{Cui} \mathrm{H} \mathrm{F,} \mathrm{et} \mathrm{al.} \mathrm{A} \mathrm{review} \mathrm{on} \mathrm{the} \mathrm{characteristics} \mathrm{and}$ the genesis of metamorphic core complexes (in Chinese). J Northwest Univ (Nat Sci Ed), 2006, 36: 793-798

16 Song C Z, Liu G S, Niu M L, et al. Cenozoic structures and dynamics on the northern margin of the Qinling-Dabie orogenic belt (in Chinese). Geol Bull Chin, 2002, 21: 530-535

17 Song C Z, Zhang G W, Ren S L, et al. The research on deformation features of some structural zones in the Qinling-Dabieshan orogenic belt (in Chinese). J Northwest Univ (Nat Sci Ed), 2009, 39: 368-380

18 Wang Z Q, Yan Q R, Yan Z, et al. New division of the main tectonic units of the Qinling orogenic belt, central China (in Chinese). Acta Geol Sin, 2009, 83: 1527-1546

19 Wang Z Q, Yan Z, Wang T, et al. New advances in the study on ages of metamorphic strata in the Qinling Orogenic Belt (in Chinese). Acta Geosci Sin, 2009, 30: 561-570

20 Dong Y P, Zhang G W, Neubauer F, et al. Tectonic evolution of the Qinling orogen, China: Review and synthesis. J Asian Earth Sci, 2011, 41: 213-237

21 Dong Y P, Zhang G W, Hauzenberger C, et al. Palaeozoic tectonics and evolutionary history of the Qinling orogen: Evidence from geochemistry and geochronology of ophiolite and related volcanic rocks. Lithos, 2011, 122: 39-56

22 Dong Y P, Genser J, Neubauer F, et al. U-Pb and ${ }^{40} \mathrm{Ar} /{ }^{39} \mathrm{Ar}$ geochronological constraints on the exhumation history of the North Qinling terrane, China. Gondwana Res, 2011, 19: 881-893

23 Dong Y P, Liu X M, Zhang G W, et al. Triassic diorites and granit- 
oids in the Foping area: Constraints on the conversion from subduction to collision in the Qinling orogen, China. J Asian Earth Sci, 2012, 47: 123-142

24 Dong Y P, Liu X M, Neubauer F, et al. Timing of Paleozoic amalgamation between the North China and South China Blocks: Evidence from detrital zircon U-Pb ages. Tectonophysics, 2012, doi.org/ 10.1016/j.tecto.2012.11.018

25 Yang J S, Xu Z Q, Ma C Q, et al. Compound orogeny and scientific problems concerning the Central Orogenic Belt of China (in Chinese). Geol Bull Chin, 2010, 37: 1-11

26 Tian Y T, Zhu C Q, Xu M, et al. Exhumation history of the Micangshan-Hannan Dome since Cretaceous and its tectonic significance: Evidence from apatite fission track analysis (in Chinese). Chin J Geophys, 2010, 53: 920-930

27 Liu J H, Zhang P Z, Zheng D W, et al. The cooling history of Cenozoic exhumation and uplift of the Taibai Mountain, Qinling, China: Evidence from the apatite fission track (AFT) analysis (in Chinese). Chin J Geophys, 2010, 53: 2405-2414

28 Bullen M E, Burbank D W, Garver J I, et al. Late Cenozoic tectonic evolution of the northwestern Tien Shan: New age estimates for the initiation of mountain building. Geol Soc Amer Bull, 2001, 113: 1544-1559

29 Chen A D, Guo T L, Wan J L. Study on the tectonic uplift of the peripheral upheaval in Jiangsu and Anhui by using fission track and isotopes dating methods (in Chinese). Geotect Metal, 2004, 28: 379-387

30 Xu C H, Zhou Z Y, P Van Den Haute, et al. Apatite-fission-track geochronology and its tectonic correlation in the Dabieshan orogen, central China. Sci China Ser D-Earth Sci, 2005, 48: 506-520

31 Li L, Zhong D L. Fission track evidence of Cenozoic uplifting events of the Taishan Mountain, China (in Chinese). Acta Petrol Sin, 2006, 22: 457-464

32 Emmel B, Jacobs J, Crowhurst P, et al. Combined apatite fission-track and single grain apatite (U-Th)/He ages from basement rocks of central Dronning Maud Land (East Antarctica) - Possible identification of thermally overprinted crustal segments? Earth Planet Sci Lett, 2007, 264: 72-88

33 Foster G L, Carter A. Insights into the patterns and locations of erosion in the Himalaya - A combined fission-track and in situ Sm-Nd isotopic study of detrital apatite. Earth Planet Sci Lett, 2007, 257: 407-418

34 Grave J D, M.buslov M, Haute P V. Distant effects of India-Eurasia convergence and Mesozoic intracontinental deformation in Central Asia: Constraints from apatite fission-track thermochronology. J Asian Earth Sci, 2007, 29:188-204

35 Vermeesch P. Quantitative geomorphology of the White Mountains (California) using detrital apatite fission track thermochronology. J Geophys Res, 2007, 112: 1-11

36 Zheng Y, Yu X Q, Wang D E, et al. Exhumation history of the Fuling granite pluton, southern Anhui: New insights from apatite fission track analysis (in Chinese). Geol Rev, 2009, 55: 385-394

37 Zheng Y, Yu X Q, Yuan W M, et al. Exhumation history of the Huangshan granite pluton, southern Anhui Province: New insights from fission-track analysis. Sci China Earth Sci, 2011, 54: 528-539

38 Wang Y T, Ye H S, Ye A W, et al. Zircon SHRIMP U-Pb ages and their significances of the Wenyu and Niangniangshan granitic plutons in the Xiaoqinling area, central China (in Chinese). Chin J Geol, 2010, 45: $167-180$.

39 Zhao H X, Jiang S Y, Frimmel H E, et al. Geochemistry, geochronology and Sr-Nd-Hf isotopes of two Mesozoic granitoids in the Xiaoqinling gold district: Implication for large-scale lithospheric thinning in the North China Craton. Chem Geol, 2012, 294-295: 173-189

40 Gao X Y, Zhao T P, Gao J F, et al. LA-ICP-MS zircon U-Pb ages, Hf isotopic composition and geochemistry of adakitic granites in the Xiaoqinling region, the south margin of the North China block (in Chinese). Geochimica, 2012, 41: 303-325

41 Xiao H, Wei J H, Tan J, et al. Geochemistry of the Early Cretaceous acidic intrusions in Xiaoqinling, central China: Constraints on tec- tonic setting (in Chinese). Geol Sci Technol Inform, 2012, 31: 39-48

42 Hurford A J. Standardization of fission track dating calibration: Recommendation by the Fission Track Working Group of the I.U.G.S. Subcommission on geochronology. Chem Geol (Isotope Geosci Section), 1990, 80: 171-178

43 Wagner G, Van Den Haute P. Fission Track Dating. Dordrecht: Kluwer Academic Publishers, 1992. 1-275

44 De Corte F, Bellemans F, Van den haute P, et al. A new U doped glass certified by the European Commission for the calibration of fission-track dating. In: Van den haute P, De Corte F, eds. Advances in Fission-Track Geochronology. Dordrecht: Kluwer Academic Publishers 1998. 67-78

45 Donelick R A, Miller D S. Enhanced TINT fission track density apatites using 252Cf-derived fission fragment tracks: A model and experimental observatuions. Nucl Trac Rad Meas, 1991, 18: 301-307

46 Green P F, Duddy I R, Gleadow A J W, et al. Thermal annealing of fission track in apatite 1: A qualitative description. Chem Geol, 1986, 59: 237-253

47 Fu M X. Review on the model of the apatite fission track annealing kinetics (in Chinese). Prog Geophys, 2003, 18: 650-655

48 Tian Y T, Yuan Y S, Hu S B. New progresses in apatite fission track analysis (in Chinese). Prog Geophys, 2009, 24: 909-920

49 Gleadow A J W, Duddy L R. A natural long-term annealing experiment for apatite. Nucl Trac Rad Meas, 1981, 5: 169-174

50 Hurford A J, Green P F. The Zeta age calibration of fission track dating. Chem Geol (Isotope Geosci Section), 1983, 1: 285-317

51 Hurford A J, Green P F. A user's guide to fission-track dating calibration. Earth Planet Sci Lett, 1982, 59: 343-354

52 Gleadow A J W, Duddy I R, Green P F, et al. Confined fission track lengths in apatite: A diagnostic tool for thermal history analysis. Contrib Mineral Petrol, 1986, 94: 405-415

53 Laslett G M, Green P F, Duddy I R, et al. Thermal annealing of fission tracks in apatite; 2: A quantitative analysis. Chem Geol (Isotope Geosci Section), 1987, 65: 1-13

54 Foster D A, Gleadow A J W, Mortimer G. Rapid Pliocene exhumation in the Karakoram (Pakistan), revealed by fission-track thermochronology of the $K_{2}$ gneiss. Geology, 1994, 22: 19-22

55 Green P F. A new look at statistics in fission track dating. Nucl Trac, 1981, 5: 77-86

56 Galbraith R F. On statistical models for fission track counts. Meth Geol, 1981, 13: 471-488

57 Gallagher K, Brown R W, Johnson C J. Fission track analysis and its applications to geological problems. Ann Rev Earth Planet Sci, 1998, 26: 519-572

58 Richardson N L, Densmore A L, Seward D, et al. Extraodinary denudation in the Sichuan Basin: Insights from low-temperature thermochronology adjacent to the eastern margin of the Tibetan Plateau. J Geophys Res, 2008, 113: B04409

59 Lee J K W, Wilians L S, Ellis D J. Pb, U and Th diffusion in nature zircons. Nature, 1997, 390: 159-161

60 Turner D L, Forbes R B. K-Ar studies in two deep basement drill holes: A new geological estimate of argon blocking for biobite. Eos, 1976, 57: 353

61 Tagami T, Galbraith R F, Yamada R. Revised annealing kinetics of fission tracks in zircon and geological implications. In Advances in Fission-Track Geochronology. Dordrecht: Kluwer Academic Publisher, 1998. 99-112

62 Liu J H, Zhang P Z, Lease R O, et al. Eocene onset and late Miocene acceleration of Cenozoic intracontinental extension in the North Qinling range-Weihe graben: Insights from apatite fission track thermochronology. Tectonophysics, 2013, 584: 281-296

63 Wang X X, Zattin M, Li J J, et al. Eocene to Pliocene exhumation history of the Tianshui-Huicheng region determined by apatite fission track thermochronology: Implications for evolution of the northeastern Tibetan Plateau margin. J Asian Earth Sci, 2011, 42: 97-110

64 Zhang Z F, Guo A L, Gong Q F, et al. Formation and evolution of the Weihe graben and the coupling relationship with its adjacent areas (in Chinese). Geol Shaanxi, 2012, 30: 6-13

65 Teng Z H, Wang X H. Studies of the tectonic uplift at the Cenozoic 
era and the regionally environmental effects in the Qinling Orogenic Belt (in Chinese). Geol Shaanxi, 1996, 14: 33-42

66 Liu H J. Tectonic uplift of the Cenozoic era in the Qinling Range (in Chinese). J Shaanxi Normal Univ (Nat Sci Ed), 2002, 30: 121-124

67 Ketcham R A, Donelick R A, Carlson W D. Variability of apatite fission-track annealing kinetics III: Extrapolation to geological time scales. Amer Miner, 1999, 84: 1235-1255

68 Wan J L, Li Q, Wang Y. The fission track evidence of Huashan batholith uplifting in Mesozoic-Cenozoic (in Chinese). Seismol Geol, 2000, 22: 51-58

69 Yin G M, Lu Y C, Zhao H, et al. The tectonic uplift of the Hua Shan in the Cenozoic (in Chinese). Chin Sci Bull (Chin Ver), 2001, 46: $1665-1668$

70 Wu Z H, Wu Z H, Wan J L, et al. Cenezoic uplift and denudation history of Huashan Mountains: Evidence from fission track thermochronology of Huashan granite (in Chinese). Geol Sci Technol Inf,
2003, 22: 27-32

71 Wu X G, Xu J H, Wei H, et al. A study of fluid inclusions of Dongtongyu gold deposit in Xiaoqinling area (in Chinese). Miner Dep, 2012, 31: 195-206

72 Wang T J, Fan B H, Guan K, et al. On the genesis of Wenyu Gold Deposit (in Chinese). Contrib Geol Miner Resour Res, 2002, 17: 85-91

73 Zhou Z J, Jiang S Y, Qin Y, et al. Fluid inclusion characteristics and ore genesis of the Wenyu gold deposit, Xiaoqinling gold belt (in Chinese). Acta Petrol Sin, 2011, 27: 3787-3799

74 Qiang S F, Bi S J, Deng X D, et al. Monazite U-Th-Pb ages of the Qinnan Gold Deposit, Xiaoqinling District: Implications for regional metallogenesis and tectonic setting (in Chinese). Earth Sci (J Chin Univ Geosci), 2013, 39: 43-56

75 Ludwig K R. ISOPLOT 3.0: A geochronological toolkit for Microsoft excel. Berkeley Geochronology Center, Special Publication 4, 2003. $1-70$

Open Access This article is distributed under the terms of the Creative Commons Attribution License which permits any use, distribution, and reproduction in any medium, provided the original author(s) and source are credited. 